\title{
Negotiation with the Self: Studying Kipling's Kimfrom the Paradigm of Identity Politics
}

\author{
NilanjanChakraborty \\ Department of English, Netaji Nagar College, India \\ Researcher, Department of English, Kalyani University, India.
}

\begin{abstract}
Kipling is one of the most enthralling authors coming out of the colonial discourse simply because he was born in India and was yet a White man, a Sahib. For him, India was a land of many wonders, often bordering on the exotic and the mysterious; even the everyday existence in India to him was a case of enthralling encounters. Kipling's Kim is a unique novel, as its interpretations of 'India' are from the perspective of the colonial master, and the resultant cultural encounter problematizes the very identity politics of the Other. There is not only a tendency to stereotype the Other, there is a subtle undertone of sentimentality about the 'land of spirituality' that seems to overtly dismiss the fact that India has any potentiality to grow into an industrial urbanised country. This paper proposes to look at the aspects of identity politics and how it disengages itself with the ground reality as the narrative travels across the mighty heartland of the subcontinent and seeks to find out, what it is to be a colonial subject in a nation where various traditions and practices intersect to create a complex web of culture.
\end{abstract}

Keywords:functionality, hyperreal, nationhood, normatively, off centre, sub-altern

It is quite interesting to note what the critical oeuvre coming out from the European circles comment on Kipling's Kimjust after the novel was published in 1901, especially if one looks at it from the critical perspective of colonial discourses:

"Over and above Kim, there is a portrait-gallery of unusual extent and interest. Mahbub Ali, the old Ressaldar, the Rajah's widow, and BabooHurree, are the chief of those who find place in it... We despair of giving our readers any adequate conception of the glorious variety of the feast here spread before them." (J.H Millar,A 'New Kipling' 283:2002). ${ }^{[1]}$

We have started our discussion from an essay of criticism in order to point out the normative structures of colonial discourses, where the cultural space of the colonized is so often stereotyped so that a narrative of the Nation can be imposed from the Imperial imagination which will be able to construct a politicized notion of the Other. Construction of nationhood is nothing but a myth, a political myth of imperial domination, but when it comes to the case of India the whole concept of nation-narration dynamics becomes more problematic because of the multicultural reality of India, and the plurality of voices that the 'natives' possess becomes an area of contention to the colonial discourses, which always have a tendency to move towards uniformity through stereopyfication. Normativity in principal British discourses constructs India on the lines of a pre-dominantly Hindu society, where the Muslim population never forms a part of the dominant colonial imagination of the British. One reason that can be proposed perhaps is the very dialectics of the colonial mission, which strives to oppress the dominant in order to create the political and ideological spaces for the centre to fit in within the colonized subject's culture so that it can be marginalized. So, it might well be argued that the Muslim culture never posited itself as a threat to this ideological turf war of the coloniser's imagination by their virtue of being the religious minority. Another interesting anecdote is of course the infamous divide and rule policy of the British, that ignited the religious bitterness in the entire sub-continent and this is emblematized by the fact that there are very few colonial authors who actually wrote about India, talked of Muslim characters. Kipling seems to have been attracted to Islamic traditions from his stay at Lahore and Bombay in his formative years, which he records in a letter written to his editor, Kay Robinson:

"- - I am deeply interested in the queer ways and works of the people of the land. I hunt and rummage among _em; knowing Lahore City-that wonderful, dirty, mysterious ant-hill-blind fold and wandering through it like Haroun Al-Raschid in search of strange things" (Kipling, Letters 127:1999). ${ }^{[2]}$

What does not however can be ignored is the typical tendency to exoticise the East, as the words "wonderful, dirty, mysterious..." create the narrative of an Islamic reality that is a mystical discovery of the Indian subcontinent which is not in synchronization with the socio-communal realities of Lahore.

The most dominant Muslim character in Kimis undoubtedly Mahbub Ali, the shrewd horse dealer, whose racial origins goes back to the South-eastern parts of Afghanistan, and he is one of the key players of the Great Game, 
along with the typified Bengali HurreeBabu- all working under the leadership of Creighton and the other Sahibs. Kipling's textual politics is well informed in the use of his language, when he uses the classic realist narrator's voice to designate Abdullah as 'the Mohammedan' (Kipling, Kim, 08:2002), ${ }^{[3]}$ even though ChotaLal, who is another childhood compatriot of Kim, is not stereotyped as anything like 'the Hindu'. Mahbub Ali's national and racial identity is similarly narrativised as the exotic, even the queer East, when Kipling writes that he hails from "...the mysterious land beyond the Passes of the North" (Kipling, Kim, 18:2002) ${ }^{[3]}$ Benedict Anderson in his seminal text Imagined Communities(1991) argues that nation construction or the very emergence of the idea of a nation is not a historical process, but is the supreme creation of modern political fiction, often expressed through print journalism and narrative fiction. In fact the term 'imagined' is rather symbolic, because the ideology of the nation has no normative ethics, nation becomes a floating signifier which can mean what its members want it to mean, though even the term 'member' has no monolithic signified. Mahbub Ali is the representative of the Muslim population of India, but is a part of the liminal cultural space whose identity is perennially garbed under suspicion because of his participation in the Great Game. The trope of the nation, the myth of its ahistorical entity is interrogated and challenged by Ali who sees the British presence in India as a necessary power equation for personal power relations to thrive- so his participation in Lurgan's colonial imagination. There are obvious racial undertones in Kipling's narrative on Ali, like "Mahbub's eyes lighted with

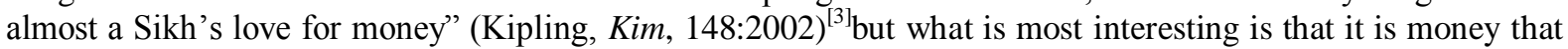
determines the power relationship between Ali and the Sahibs, as also with Kim. When Kim is put into the British secret service training, it is to Mahbub Ali that Kim turns to in order to seek for the financial support which determines the fact that the Muslim identity of Ali is equated with financial power and social dominance. Charles Allen writes to the young Kipling "wrote with growing sensitivity about Islam and Muslims"(2327:2009), ${ }^{[4]}$ and this sensitivity is delineated when Kim temporarily misjudges Mahbub Ali's role in the Great Game, soon to realize however that Ali is as much a victim from the perspective of a colonized subject as he himself perhaps is, or is HurreeBabu. Kim himself suffers from a very problematic ethnic background, given his maternal Irish lineage and this reaches a perfect narrative blending with Mahbub Ali, the latter being already a figure of marginalization due to his status as the religious minority. It is even an ironic narrative strategy on the part of Kipling to include the Buddhist lama as the mentor to Kim when he goes to St. Xavier's as Buddhism was already a very liminal religious group in India by the beginning of twentieth century.

The human face of Mahbub Ali is reinstated as his commitment to Kim as the foster father- this is something that Kipling handles very sensitively because the power politics of the Great Game has taught the man the need to be closer to the power centre in order to survive socially or politically, being a part of the colonized subject. Ali's hope that "He played with my horses when he was a babe. Now I think they will make him a soldier" (Kipling, Kim, 93:2002) ${ }^{13}$ is entrenched in a deep rooted insecurity about Kim's future within the empire, given his Irish background and his identity of not being an 'Indian'. DipeshChakrabarty while talking about the construction of nationalist history observes:

"As such a split subject, however, it [national history] speaks from within a metanarrative that celebrates the nation state; and of this metanarrative the theoretical subject can only be a hyperreal 'Europe', a 'Europe' constructed by the tales thatboth imperialism and nationalism have told the colonized" (DipeshChakrabarty, 1992) ${ }^{[5]}$

Kim in the novel becomes the site of thehyperreal Europe, where the Irish history conglomerates with his half Indian ethnicity, as far his identity of 'becoming' an Indian is concerned, and the chief proponent for this metanarrative transition is Mahbub Ali. Imperialistic imagination has taught Ali to give Kim the language of the colonizer, without which Kim's position in India is in danger of spiraling into a severe identity crisis, and nationalistic history has imbibed the Muslim identity in Ali with which he is able to preserve his own vision of a humane India despite being a part of the Great Game. What stops us from identifying Mahbub Ali as a subaltern is his financial repudiation, but his socio-political standing is problematized by his role as an inside/outside player of the Great Game, both participating and rebuking the British colonial power to construct a counter power centre of his own. The question of identity is rather significant, as Mahbub Ali says to Lurgan: "I am a Pathan; thou art a Sahib and the son of a Sahib" (Kipling, Kim, 125:2002) ${ }^{[3]}$ which is almost selfassertion of Ali of his Muslim subject position. But what strikes as remarkable is the narrator's voice who comments about "the tone" that Mahbub Ali uses "towards Europeans" (Kipling, Kim, 125:2002), ${ }^{[3]}$ which reflects the site of cultural coercion within the garb of apparent coalition. The novel is about a religious as well as cultural quest to establish identity and find the 'home' that eludes almost all the characters in the fictional world, and Ali repeatedly comes up with invocations to Allah, but instead of creating a contentious religious fanaticism, Ali ends up being the supreme symbol of acceptance and an agnostic philosophy of life, and this is where the crossroads of his life meets with Teshoo Lama.

It will be worthwhile to note what Amitav Ghosh says about the ideology of the construction of nationhood, to create what Salman Rushdie has called the imaginary homeland: 
"That is the trouble with an infinitely reproducible space; since it does not refer to actual places it cannot be left behind... Eventually the place and the realities that accompany it vanish from the memory and... the place, India, becomes in fact an empty space, mapped purely by words." (Ghosh, Imam 248-9:2002) [6] $^{[6]}$

The "words" that Ghosh talks about is the spatial quality of the nation that is filled by memories, nostalgic narration and constructed fictionality that ultimately causes culture to be a floating signifier. Kim's incessant quest for an identity creates this India that is mapped by words- mapped by the sites of Kim's picaresque experiences, which brings him closer to the Musalman identity. The initiation of Kim, as it were, to Islamic discourses as done by Mahbub Ali-“He made Kim learn whole Chapters of the Koran" (Kim, 143:2002), ${ }^{[3]}$ which is quite significant because it brings Kim closer to the Islamic traditions in a subcontinent where Hinduism is the dominant religious narrative. It sparks the childhood fantasies of Kim, the world of the Koran seems to be a world of fantasy for him- of course the textual politics of the Occidental/Oriental dialectics is more than evident to marginalize Islam as the 'fantastical' and therefore unreal. The image of dresses becomes the agents of identity construction as Kim wears "... gold embroidered Peshawur turban-cap" (Kim, 144:2002) ${ }^{[3]}$ and later he dresses up as a Faquir to evade the police- all contributing to the fluid identity of Kim before he finally reaches at some kind of identity at the end of the text, which is quite typical for an early twentieth century fiction. At this point it might be crucially critical to analyse what Kipling himself thinks about the Islamic tradition and its cultural practices. In a letter to Margaret Burne-Jones in 1885, Kipling notes-

"Frankly, both he[Pater] and I prefer Mussalmans to Hindus; they're a better lot roughly speaking." (Kipling, Kim 268:2002) ${ }^{[7]}$

The semiotic space of identity creation then becomes the site of contestation, with both Islam and Buddhism striving their way into the socio-cultural psyche of an adolescent boy which leads him to interrogate whether he is a Mussalman, a Hindu or a Buddhist. The politics of representation becomes a crucial factor in incorporating Kim within the folds of Mahbub Ali; both cannot represent their cultural self within the claustrophobia of the Great Game. They are Anglicized to the extent that they must play a part in the roles assigned to them, or they have the danger of getting perished. The lama's generosity in helping Kim to get into St.Xavier's by giving a financial assistance makes Mahbub Ali insecured. The latter is all too eager to play the role of the foster-father that gives him a chance to remain close to the power centre with Kim's Irish descent and his racial identity of a Sahib- something that he can ill afford to miss.

Edward Said, in his observation on the textual politics related to the representation of the East by western authors, notes:

"It is as if ... a bin called 'Oriental' existed into which all the authoritative, anonymous, and traditional Western attitudes to the East were dumped unthinkingly..." (Said, Orientalism 297:2005) ${ }^{[8]}$

This dumping of the Western stereotyped normativity about the Orient is delineated in the characterization of Huneefa, the seductress who is made mysterious in the way she plays the role of a priestess and an absent mother motif in Kim's life. The Oriental woman is mystified as some goddess from the underworld with her hookah, heavy jewellery and sensual lips- the phallocentric patriarchy subjects her to the cultural norm of the use of the body for the patriarchy that produces it. The neurotic fear for the female force is made emblematic through Kim's fear of the Islamic chants as he pushes himself back more and more into his male space, even when the religious rite of Islamic invocations is invigilated upon by Mahbub Ali:

"Huneefa, now whispering in his ear... touched him with horrible soft fingers..." (Kim 151:2002, emphasis added $)^{[3]}$

Huneefa therefore epitomizes the fear of the charming East, which Kim feels even after being brought up in India as an orphan. There is an implicit comparison of Huneefa with the woman in Shamlegh, for whom Kim feels no such cultural threat because after all she is a Christian, her God is Kim's God and her domain has a religious familiarity with that of Kim's. Yet, Muslim identity is something that Kim incessantly tries and construct for his self inspite of arriving as the real chela to the lama at the end of the text, where the lama declares that his agnostic quest for eternal freedom lies in leading his chela towards the path of eternal freedom. When the lama announces the project to Kim, he responds with an "Allah kerim" which perhaps negate any possibility of Kim becoming a Buddhist. However, more than the institutionalized belief, Kim sees the Islamic God as the progenitor of love, care and companionship-qualities of social bonding and communal brotherhood that Kim fails to get when he was a part of the Great Game. Even Mahbub Ali, who is now a tired soul, especially after the assassination attempt on him struggles to get rid of all the social anomalies of identity creation. He claims to be a Sufi, embracing the same quest for nirvana like that of the lama as he says: "On that, then, he goes to Jannatul'Adn. But how?" (Kim 236:2002). ${ }^{[3]}$ The overt physical awareness that Mahbub Ali has of Kim at the end of the text almost points out to a homoerotic tension that exists between the foster-father and his son but it seems beyond doubt, that after so many years in Ali's apprenticeship, the initiation into Muslim identity that has taken place has deeply entrenched into the ontological psyche of Kim. 
The cultural capital helps in the acquisition of specific cultures as knowledge, and there is no economy on this acquisition as far as Kim is concerned- his picaresque experiences finally help him to arrive at the identity creation of Kim the traveler. Zohreh T. Sullivan observes that at the end of the text, "...there is less fear of the unknown because it is now only a space to be colonized and mapped into knowledge" (Sullivan, "What Happens at the End of Kim' 443:2002) ${ }^{[9]}$ The opposition between the museum in Lahore and the gun that Kim held is made more prominent here when Mahbub Ali hands him the gold chain, signifying that Muslim appearance can help Kim to internalize the colonial India within him, as he can take possession of his own identity with purported force. Like the character McIntosh Jellaluddin in Kipling's short story To Be Filed for Reference,Kim also hangs in the midair at the end of the novel, sharing with his readers the same sense of anxiety of a blurred identity. Mapping of knowledge is always a daemonic Alice-through-the-looking-glass kind of quasi-analogue of a deflected, off-centre kind of experience that exposes the fissures and breakages in a carefully constructed self-identity. The discursive space of identity is always an open field of multiinterpretations, Foucault observing on this note:

"The modes of circulation, valorization, attribution, and appropriation of discourses vary with each culture and are modified within each."(Foucault, 'What is an Author' 203:2005) ${ }^{[10]}$

Therefore, the discursive cultures of Islam and Buddhism, along with the colonial mission-all are interpreted and re-interpreted within the contested site of Kim's cultural self and at the end of the text he remains quite unsure of his identity. The final interaction between Mahbub Ali and the lama showcases two men battling for their possession, but it is Ali who makes the sacrifice and retreats because he is aware of Kim's fascination for the lama. Kim touches the feet of the lama in the posture of a Mohammedan, which attributes to his deep rooted negotiations with Islam. Foucault's modification of the cultural discourses within a cultural system comes when Kim reaches at the realization that his self is ultimately fluid with a desire towards the lama's Buddhist identity, but at the same time he also has the cultural baggage of Islam when he has been a part of the Great Game under Mahbub Ali. Mahbub Ali's final retreat might signify the closure of the Islamic presence in Kim's life, but the psychological rootedness that he once had with the Zam-zammah in Lahore remains as an undeniable presence in his ontological being. Kim will not "...mount Mohammed's Horse and fly away" (Kim 236:2002) ${ }^{[3]}$ as Mahbub Ali fears, but the Islamic traditions will remain a part of his fissured identity as he follows the lama into the world of travel, quest and nirvana.

\section{References}

[1] Millar, J.H. Kim. New York: W.W Norton \& Company, Inc, 2002. Print.

[2] Kipling Rudyard. Letters 4 vols,ed by Thomas Pinney. Iowa City: University of Iowa Press, 1990-1999, vol.1, 127. Print.

[3] Kipling Rudyard. Kim New York: W.W Norton \& Company, Inc, 2002. Print.

[4] Allen, Charles. "Ruddy's Search for God: the Young Kipling and Religion" The Kipling Journal 32 (June 2009): 23-37. Print.

[5] Chakrabarty, Dipesh. "Postcoloniality and the Artifice of History: Who Speaks for "Indian" Pasts?" Representations 37(Winter), 1992. Print.

[6] Ghosh, Amitav. Imam and the Indian New Delhi: Ravi Dayal, 2002. Print.

[7] Kipling Rudyard. "Letters". In Kim New York: W.W Norton \& Company, Inc, 2002. Print.

[8] Said, Edward.Culture in orientalism 1978.New Delhi: Pearson Education, 2005. Print.

[9] Sullivan, Zohreh.T. "What Happens at the End of Kim?" In Kim. New York: W.W Norton \& Company, Inc, 2002. Print.

[10] Foucault, Michel. What is an Author?Trans. Joseph V. Harari.New Delhi: Pearson Education, 2005. Print. 